\title{
Conductivity Measurements of 4-Amino Salicylic Acid and with some Transition Metal Chlorides in Different Solvents and at Different Temperatures
}

\author{
Banan A. Akrawi Ahlam M. J. Ali* Alaa H. Jalil \\ Department of Chemistry/ College of Science/ University of Mosul \\ *Email: pro_ahlam@yahoo.com
}

(Received 16/5/2013;Accepted 26/6/2013)

\begin{abstract}
In the first part of this work we have measured the electrical conductivity of 4-amino salicylic acid (4-ASA) solution in water, methanol and ethanol at different temperatures (293.16-313.16 K). The experimental results were analyzed using Lee-Wheaton equation (LW) for symmetrical electrolytes $(1: 1)$. The conductivity parameters were calculated: the equivalent conductivity at infinite dilution $\left(\Lambda_{0}\right)$, the association constant $\left(\mathrm{K}_{\mathrm{A}}\right)$ and the mean distance values between ions $(\mathrm{R})$ at the best standard deviation $\sigma \mathrm{s}(\Lambda)$. It is found that by increasing the temperature, the values of $\Lambda_{\mathrm{o}}$ increased, in contrast of that the values of $\mathrm{K}_{\mathrm{A}}$ decreased in ethanol only, $\mathrm{R}$ are found to be between (2-29) $\mathrm{A}^{\mathrm{o}}$ which indicates the formation of solvent separated ion pairs in solution. By Vant Hoff equation we have calculated the thermodynamic parameters $(\Delta \mathrm{G}, \Delta \mathrm{H}$ and $\Delta \mathrm{S})$ of ion association in solution.

The second part of this work is the measurement of electrical conductivity of (4-ASA) in water with chlorides of each of nickel, cobalt and manganese at different temperatures (293.16$313.16 \mathrm{~K}$ ) and calculation of conductivity parameters by Lee-Wheaton equation for unsymmetrical electrolytes (2:1), besides the thermodynamic parameters were also performed. The Walden-product $\left(\Lambda_{0} \eta\right)$ was also determined and discussed.
\end{abstract}

Keywords: Conductivity, Lee-Wheaton equation, 4-amino salicylic acid, association constant

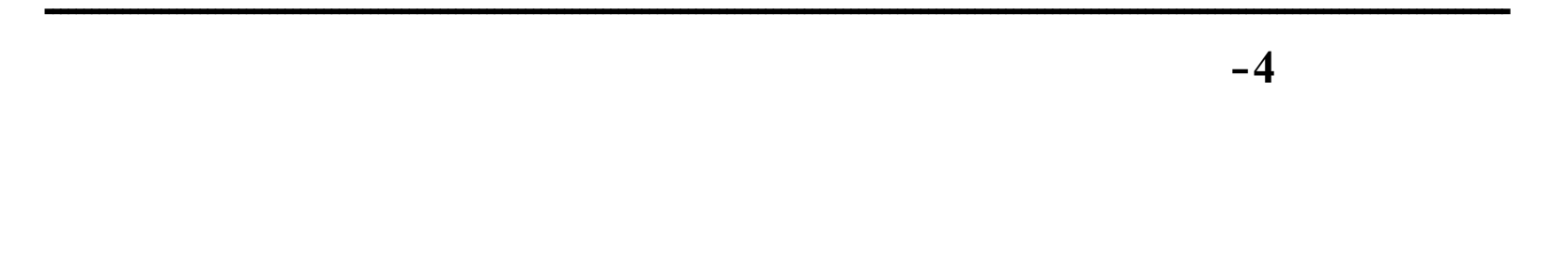

في الجزء الأول من هذا البحث م قيلس التوصيلية الكهربائية لمحلول 4 -امينو حمض السللسيليك في مذيبلت كل من ماء قيلس المواصلة والميثانول فضلا عن الايثانول وفي درجلت حرارية مختلفة (293.16-313.16). وقم تحليل النتائج العملية بظبق معادلة لي_ويتون في التوصيلية للاليكتروليتات المتنظرة (1:1) ومسبب متغيرات التوصيلية: المواصلة

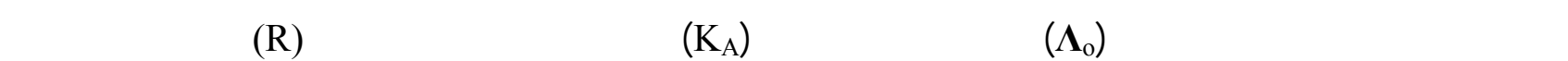
الانحراف القيلهي (ب) كل من الماء والميثانول في حين انها نقل في مذيب الايثانول وان قيم R R (2-29A ) مما يدل على تكوين مزدوجلت اليونية

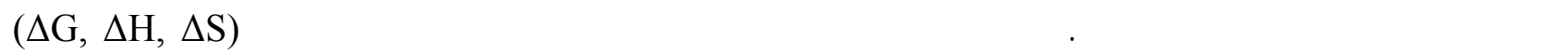
للتجمع الايوني في المحلول.

والجزء الثاني من البحث يتضمن قيلس التوصيلية الكهربائية لمحلول 4 -لمينو حمض السللسيليك في الماء مع كلوريدات كل من النيكل والكوبلت والمنغنيز وفي درجلت حرارية مختلفة (293.16-313.16 ) ومسلب متغيرات التوصيلية 
بلستخدلم معادلة لي_ويتون للاليكتروليتلت غير المتنظرة (2:1) فضلا عن مسلب الدوال الثرموداينميكية وأيضا نوقثت النتائيج

الكاملت الدالة: التوصيلية الكهربائية، 4 -امينو حمض السللسيليك، معادلة لي_ويتون، ثابت التجمع الايوفي،مزدوجلت اليونية.

INTRODUCTION

4-amino salicylic acid is an antibiotic used to treat tuberculosis (Wikipedia, 2013). This organic compound has also been used since 1940, for the treatment of inflammatory bowel disease, where it has shown a greater potency in ulcerative colitis and Crohn's disease. 4-ASA has been investigated for the use in manganese chelating therapy and a 17-year follow-up study shows that it might be superior to other chelating protocols such as EDTA. With heat amino salicylic acid is decarboxylated to produce $\mathrm{CO}_{2}$ and 3-amino phenol (daily med, 2013).

The dissociation constant of salicylic acid in 1-propanol-water mixtures at $25^{\circ} \mathrm{C}$ has been determined from conductance measurements. The experimental data have been analyzed by means of (LW) equation (Papadopoulos and Avranas, 1991). The ionization constants of acids are influenced by the nature of the solvent and especially in alcohol-water mixtures vary with solvent composition in a manner which is not completely understood (Niazi and Khan, 1993). Conductance provides a simple and accurate method for the determination of the dissociation constant of a relatively strong acids (Niazi et al., 1993).

In the present works the conductivity parameters have been calculated for (4-ASA) with their mixtures of some transition metal chlorides in different solvents and at different temperatures.

\section{Chemicals and reagents:}

\section{EXPERIMENTAL}

4-amino salicylic acid (analar grade) and the transition metal chlorides were reagent grade (BDH) products used without any further purification.

\section{Solvents:}

Absolute methanol and absolute ethanol were of (BDH) products. Conductivity water was prepared by redistilling distilled water three times with the addition of a little amount of potassium permanganate and small pellets of $\mathrm{KOH}$.

\section{Instruments:}

The conductivity measurements were made using a digital conductivity meter (Jenway) with sensitivity between $10^{-1}$ and $10^{-9}$ Siemens.

\section{General procedure:}

A general method has been used for measuring the conductance of the electrolytes. The conductivity cell was dried and kept at a contrast temperature $\left( \pm 0.1{ }^{\circ} \mathrm{C}\right)$. A certain volume $(25 \mathrm{ml})$ of conductivity water (or any solvent used) was placed in the conductivity cell, then a small volume of (4-ASA) $\left(1 \times 10^{-3} \mathrm{M}\right)$ was added and the conductivity of the solution was measured. This procedure was repeated by different additions of (4-ASA) for about (12-16) times for each run. The whole procedure was repeated at each temperature.

The second part of this work was as following: in a clean dried conductivity cell, a certain amount $\left(10 \mathrm{ml}\right.$ of $\left.5 \times 10^{-5} \mathrm{M}\right)$ of each metal chloride solution was placed in the conductivity cell and then a small known volume of $\left(5 \times 10^{-5} \mathrm{M}\right)(4$-ASA) was added and the conductivity was measured followed by (12-16 times) of (4-ASA) additions and measuring the conductivity for each solution. This procedure was repeated again at different temperatures. 


\section{RESULTS AND DISCUSSION}

The results of the present work were analyzed according to (LW) equation for the specific case of solution containing only a single symmetrical electrolyte indicates that $\Lambda_{\text {equiv. }}$ is a function of many parameters as:

$$
\Lambda_{\text {equiv. }}=\mathrm{f}\left(\Lambda_{\mathrm{o}}, \mathrm{R}, \mathrm{K}_{\mathrm{A}}\right)
$$

Where $\Lambda_{\mathrm{o}}$ is the equivalent conductance at an infinite dilution, $\mathrm{K}_{\mathrm{A}}$ is the pair-wise ion association constant:

$$
\mathrm{M}^{+}{ }_{\mathrm{aq}}+\mathrm{X}^{-}{ }_{\mathrm{aq}} \underset{\mathrm{K}}{\longrightarrow} \mathrm{M}^{+}{ }_{\text {n.aq }} \mathrm{X}^{-}
$$

Where $\mathrm{n}$ is the number of solvent molecule and may be zero, and $\mathrm{R}$ is the distance parameter between anion and cation.

The input data to the computer program $\{(\mathrm{LW})$ equation for $(1: 1)$ symmetrical electrolytes $\}$ are: solvent data (Temp. T, Dielectric constant $\mathrm{D}$, Viscosity $\eta$ ); $\mathrm{K}_{\mathrm{A}} ; \Lambda_{\mathrm{o}}$; and $\mathrm{R}$ in the form of $\mathrm{R}_{\min \text {., }}$ $\mathrm{R}_{\text {max. }}$, the minimum and maximum distance between ions), $\Delta \mathrm{R}$, together with the solution molarities $\left(\right.$ mol. $\left.\mathrm{L}^{-1}\right)$ and the corresponding equivalent conductance $\left(\right.$ Siemens equiv $\left.{ }^{-1} . \mathrm{cm}^{2}\right)$.

This program calculates the values of $\Lambda_{0}, K_{A}$, and $R$ (the characteristic ion-pair distance parameter) which gives the "best fit " of the experimental conductance.

Table (1) shows the variation of the equivalent conductivity with molar concentration of 4amino salicylic acid in different solvents at different temperatures. 


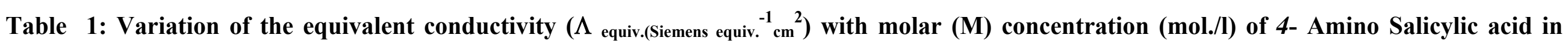
different solvents at different temperatures.

\begin{tabular}{|c|c|c|c|c|c|c|c|c|c|c|c|c|c|c|c|}
\hline \multirow{2}{*}{$\begin{array}{c}\text { Solvent } \\
\text { Temp./ } \\
\text { K }\end{array}$} & \multicolumn{5}{|c|}{ Water } & \multicolumn{5}{|c|}{ Methanol } & \multicolumn{5}{|c|}{ Ethanol } \\
\hline & 293.16 & 298.16 & 303.16 & 308.16 & 313.16 & 293.16 & 298.16 & 303.16 & 308.16 & 313.16 & 293.16 & 298.16 & 303.16 & 308.16 & 313.16 \\
\hline$M \times 10^{4}$ & $\Lambda_{\text {equiv. }}$ & $\Lambda_{\text {equiv. }}$ & $\Lambda_{\text {equiv. }}$ & $\Lambda_{\text {equiv. }}$ & $\Lambda_{\text {equiv. }}$ & $\Lambda_{\text {equiv. }}$ & $\Lambda_{\text {equiv. }}$ & $\Lambda_{\text {equiv. }}$ & $\Lambda_{\text {equiv. }}$ & $\Lambda_{\text {equiv. }}$ & $\Lambda_{\text {equiv. }}$ & $\Lambda_{\text {equiv. }}$ & $\Lambda_{\text {equiv. }}$ & $\Lambda_{\text {equiv. }}$ & $\Lambda_{\text {equiv. }}$ \\
\hline 0.19 & 319.40 & 288.19 & 267.38 & 251.78 & 236.17 & 26.01 & 23.41 & 19.77 & 16.65 & 13.01 & 4.68 & 4.16 & 3.64 & 3.12 & 2.60 \\
\hline 0.38 & 260.96 & 237.09 & 218.52 & 207.92 & 194.66 & 16.71 & 13.53 & 11.14 & 9.28 & 7.69 & 3.18 & 2.65 & 2.12 & 1.86 & 1.59 \\
\hline 0.56 & 231.38 & 215.16 & 198.94 & 186.33 & 173.71 & 12.43 & 9.55 & 7.93 & 6.67 & 5.59 & 2.52 & 1.98 & 1.62 & 1.44 & 1.26 \\
\hline 0.74 & 216.74 & 201.59 & 186.45 & 174.05 & 161.66 & 9.64 & 7.57 & 6.33 & 5.23 & 4.54 & 2.07 & 1.65 & 1.38 & 1.24 & 1.10 \\
\hline 0.90 & 205.77 & 190.07 & 176.60 & 165.38 & 154.16 & 8.30 & 6.28 & 5.39 & 4.38 & 3.93 & 1.80 & 1.46 & 1.23 & 1.12 & 1.01 \\
\hline 1.07 & 196.49 & 184.12 & 170.79 & 159.36 & 147.94 & 7.24 & 5.43 & 4.86 & 4.00 & 3.52 & 1.62 & 1.33 & 1.14 & 1.05 & 0.95 \\
\hline 1.23 & 188.87 & 175.58 & 163.95 & 154.82 & 144.02 & 6.48 & 4.90 & 4.40 & 3.74 & 3.32 & 1.50 & 1.25 & 1.08 & 1.00 & 0.91 \\
\hline 1.38 & 182.21 & 168.90 & 158.55 & 150.41 & 139.32 & 5.84 & 4.51 & 4.07 & 3.48 & 3.11 & 1.41 & 1.18 & 1.04 & 0.96 & 0.89 \\
\hline 1.53 & 176.13 & 162.75 & 154.06 & 146.71 & 136.68 & 5.35 & 4.28 & 3.81 & 3.21 & 2.94 & 1.34 & 1.14 & 1.00 & 0.94 & 0.87 \\
\hline 1.67 & 170.38 & 158.14 & 148.96 & 142.23 & 133.66 & 5.02 & 4.10 & 3.61 & 3.12 & 2.88 & 1.29 & 1.10 & 0.98 & 0.92 & 0.86 \\
\hline 1.80 & 166.52 & 152.95 & 145.59 & 139.37 & 132.02 & 4.86 & 3.96 & 3.45 & 3.00 & 2.77 & 1.24 & 1.07 & 0.96 & 0.91 & 0.85 \\
\hline 1.94 & 162.00 & 149.35 & 140.92 & 135.65 & 129.33 & 4.64 & 3.79 & 3.32 & 2.90 & 2.69 & 1.21 & 1.05 & 0.95 & 0.90 & 0.84 \\
\hline 2.06 & 158.38 & 145.52 & 139.10 & 134.16 & 127.23 & 4.45 & 3.66 & 3.21 & 2.82 & 2.62 & 1.19 & 1.04 & 0.94 & 0.89 & 0.84 \\
\hline 2.19 & 154.99 & 142.40 & 136.81 & 132.15 & 125.62 & 4.24 & 3.59 & 3.12 & 2.75 & 2.56 & 1.17 & 1.03 & 0.93 & 0.89 & 0.84 \\
\hline 2.31 & 151.78 & 139.41 & 134.99 & 130.57 & 125.26 & 4.07 & 3.45 & 3.05 & 2.70 & 2.52 & 1.15 & 1.02 & 0.93 & 0.88 & 0.84 \\
\hline 2.42 & 149.11 & 136.91 & 132.70 & 128.50 & 124.29 & 3.96 & 3.32 & 2.99 & 2.65 & 2.44 & 1.14 & 1.01 & 0.93 & 0.88 & 0.84 \\
\hline 2.54 & 146.49 & 134.83 & 131.21 & 127.19 & 123.17 & 3.82 & 3.22 & 2.93 & 2.61 & 2.37 & 1.13 & 1.01 & 0.92 & 0.88 & 0.84 \\
\hline 2.65 & 144.27 & 132.71 & 129.24 & 125.39 & 121.53 & 3.70 & 3.12 & 2.89 & 2.58 & 2.31 & 1.12 & 1.00 & 0.92 & 0.89 & 0.85 \\
\hline 2.75 & 142.39 & 130.17 & 127.94 & 124.24 & 120.54 & 3.63 & 3.04 & 2.85 & 2.59 & 2.26 & 1.11 & 1.00 & 0.93 & 0.89 & 0.85 \\
\hline 2.86 & 140.09 & 128.31 & 126.52 & 122.95 & 119.38 & 3.57 & 2.96 & 2.82 & 2.61 & 2.21 & 1.11 & 1.00 & 0.93 & 0.89 & 0.86 \\
\hline
\end{tabular}



$(1-3)$.

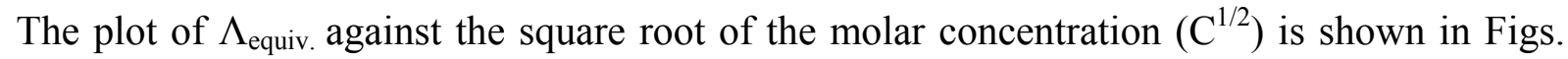

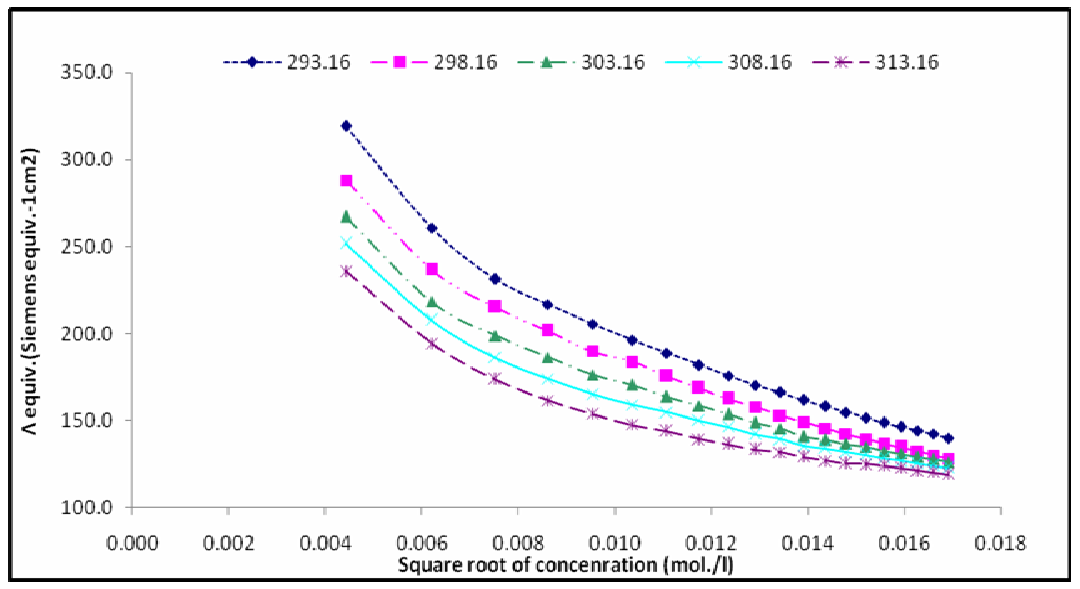

Fig. 1: The relation between equivalent conductivity and the square root of concentration of 4-Amino Salicylic acid in water at different temperatures

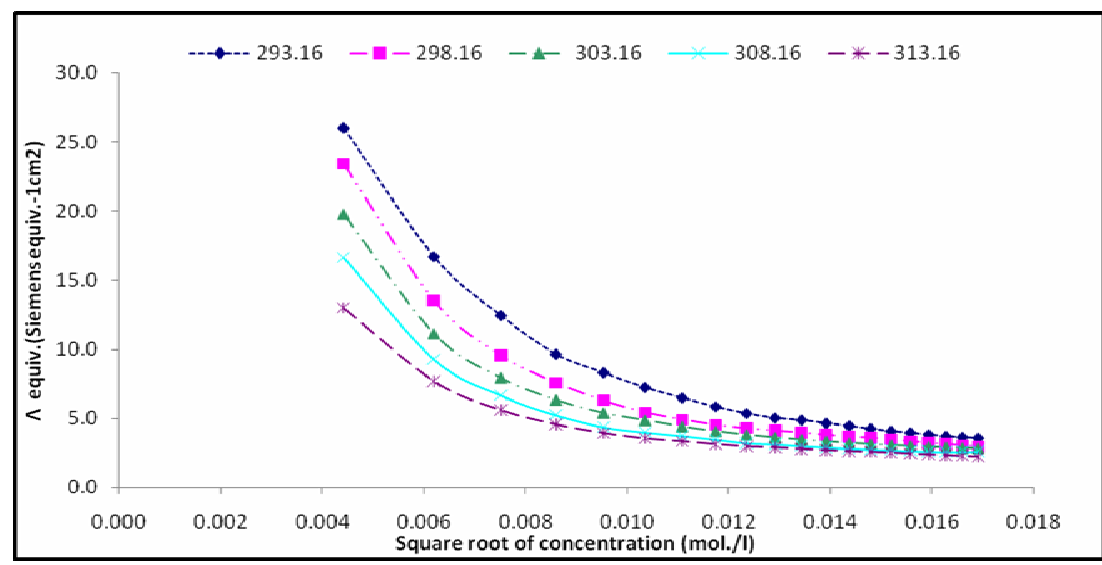

Fig. 2: The relation between equivalent conductivity and the square root of concentration of 4-Amino Salicylic acid in methanol at different temperatures

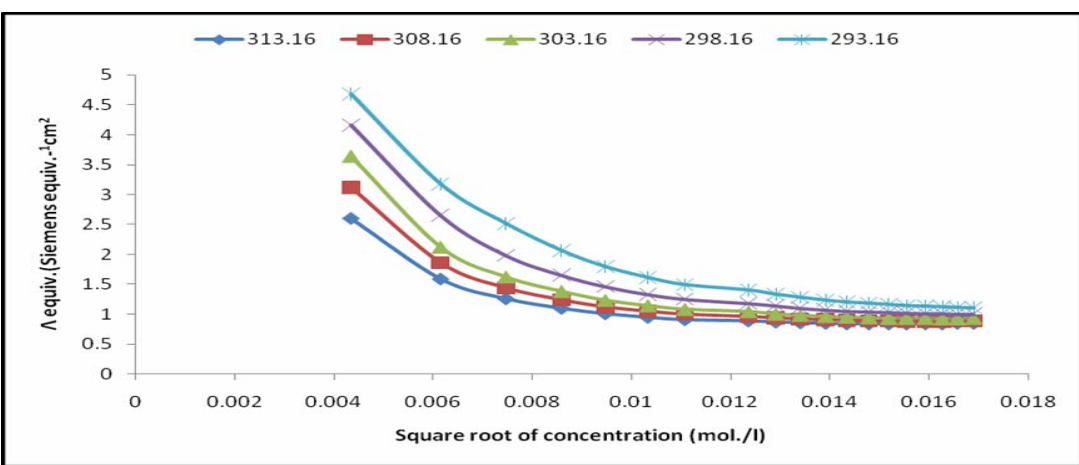

Fig. 3: The relation between equivalent conductivity and the square root of concentration of 4-Amino Salicylic acid in ethanol at different temperatures

It is clear from the plot that the compound behaves as a weak electrolyte at different temperatures in each solvent. Table (2) shows the best fit parameters of analysis of conductance data by using (LW) equation. 
Raf. J. Sci., Vol. 25, No.3, pp. 24-37, 2014------

Table 2: Best fit parameters of analysis of conductance data for 4-ASA in water, methanol and ethanol at different temperatures

\begin{tabular}{|c|c|c|c|c|c|c|c|c|c|c|c|c|}
\hline \multirow{2}{*}{$\begin{array}{c}\text { Solvent } \\
\text { Temp. } \\
\text { (K) }\end{array}$} & \multicolumn{4}{|c|}{ Water } & \multicolumn{4}{|c|}{ Methanol } & \multicolumn{4}{|c|}{ Ethanol } \\
\hline & $\begin{array}{c}\boldsymbol{\Lambda}_{\mathbf{o}} \\
\text { Siemens } \\
\text { equiv } \\
{ }^{-} . \mathrm{cm}^{2} \\
\end{array}$ & $\mathbf{K}_{\mathbf{A}}$ & $\mathbf{R} / \mathbf{A}^{\mathbf{o}}$ & $\sigma \mathbf{s}(\Lambda)$ & $\begin{array}{c}\boldsymbol{\Lambda}_{\mathbf{o}} \\
\text { Siemens } \\
\text { equiv } \\
11 \mathrm{~cm}^{2} \\
\end{array}$ & $\mathbf{K}_{\mathbf{A}}$ & $\mathbf{R} / \mathbf{A}^{\mathbf{0}}$ & $\sigma \mathbf{s}(\boldsymbol{\Lambda})$ & $\begin{array}{c}\boldsymbol{\Lambda}_{\mathbf{o}} \\
\text { Siemens } \\
\text { equiv } \\
1 . \mathrm{cm}^{2} \\
\end{array}$ & $\mathbf{K}_{\mathbf{A}}$ & $\mathbf{R} / \mathbf{A}^{\mathbf{o}}$ & $\sigma \mathbf{s}(\Lambda)$ \\
\hline 293.16 & 357.37 & 13981 & 9 & 0.035 & 41.95 & 195763 & 2 & 0.066 & 5.32 & ---- & 19 & 0.095 \\
\hline 298.16 & 355.30 & 17374 & 9 & 0.025 & 39.47 & 200728 & 2 & 0.730 & 4.86 & 56786 & 19 & 0.009 \\
\hline 303.16 & 309.90 & 13494 & 19 & 0.035 & 58.24 & 274555 & 10 & 0.316 & 4.35 & 46538 & 19 & 0.002 \\
\hline 308.16 & 281.66 & 11533 & 19 & 0.043 & 33.38 & 300448 & 10 & 0.804 & 3.8 & 36720 & 26 & 0.002 \\
\hline 313.16 & 257.92 & 10528 & 29 & 0.053 & 29.54 & 343951 & 10 & 0.026 & 2.11 & 1746 & 26 & 0.170 \\
\hline
\end{tabular}


The analysis shows that $\Lambda_{0}$ decreases with the increasing temperature. In methanol the increasing of $\mathrm{K}_{\mathrm{A}}$ assumes a simple coulombic interaction between hard sphere ions in continuous medium. Besides the dielectric constant of the solvent which play an important role on the ionic conductivity, it decreases with increasing temperature, since oppositely charged ions tend to form ion-pairs and the interionic forces in an electrolytic solution are assumed in the various theoretical treatments, to follow coulombs law and so to be inversely proportional to the dielectric constant of the solution which have an important effect on the values of the association constant $\left(\mathrm{K}_{\mathrm{A}}\right)$ as the $\mathrm{K}_{\mathrm{A}}$ values increase with increasing temperature assuming a simple coulombic interaction between hard sphere ions in a continuous medium (Akrawi et al., 2006) (Fuoss, 1958). In other words, it is expected that such an increase of $\left(\mathrm{K}_{\mathrm{A}}\right)$ is partly due to a decrease in the dielectric constant and can partly be explained in terms of diminution in dielectric constant in the vicinity of an ion-pair and decreasing the density of solvent (Weast, 1974).

In both water and ethanol each of $\mathrm{K}_{\mathrm{A}}$ and $\Lambda_{\mathrm{o}}$ decreased with increasing temperature. This behavior can be explained as that the coulombic interactions cannot explain the acid association constants and that some form of short range interaction is required to explain the results for the compound in different temperatures (Niazi et al., 1993), (Ali, 2006).

Standard thermodynamic quantities for the association were evaluated by the least-square treatment of the plot of $\ln \mathrm{K}_{\mathrm{A}}$ against 1/T, Fig. (4).

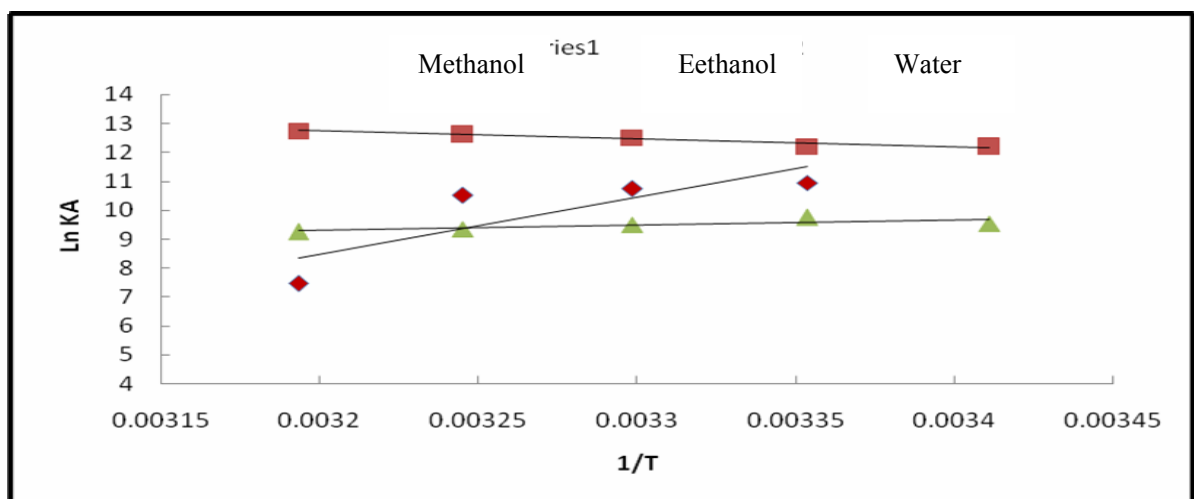

Fig. 4: The plot of $\operatorname{Ln} K_{A}$ against 1/T for 4-ASA in different solvents

$$
\ln K_{A}=-\Delta H^{\mathrm{a}} / R T+C \ldots .
$$

The standard entropy of ion-pair formation is a linear combination of two variables:

$$
\Delta S^{\circ}=\frac{\left(\Delta H^{\circ}-\Delta G^{\circ}\right)}{T} \ldots \ldots \text { (2) }
$$

The standard Gibb's energy calculated from the relationship

$$
\Delta G^{\circ}=-R T \ln K_{A} \ldots \ldots \ldots \text { (3) }
$$

The results of calculation are gathered in (Table 3 ). 
Table 3: Thermodynamic parameters from the ion-association constant of (4-ASA) in different solvents at different temperatures

\begin{tabular}{|c|c|c|c|c|c|c|c|c|c|}
\hline Solvent & \multicolumn{3}{|c|}{ Water } & \multicolumn{3}{|c|}{ Methanol } & \multicolumn{3}{|c|}{ Ethanol } \\
\hline $\begin{array}{c}\text { Temp. } \\
\text { (K) }\end{array}$ & $\begin{array}{c}-\Delta \mathbf{H} \\
\text { KJ.mol }^{-1}\end{array}$ & $\begin{array}{c}-\Delta \mathbf{G} \\
\text { KJ.mol }^{-1}\end{array}$ & $\begin{array}{c}-\Delta \mathrm{S} \\
\text { J. } \mathrm{K}^{-1} \mathrm{~mol}^{-1}\end{array}$ & $\Delta \mathrm{H} \mathrm{KJ.mol}{ }^{-1}$ & $\begin{array}{c}-\Delta \mathbf{G} \\
\text { KJ.mol }^{-1}\end{array}$ & $\begin{array}{c}\Delta S \\
J \cdot \mathbf{K}^{-1} \mathbf{m o l}^{-1}\end{array}$ & $\begin{array}{c}-\Delta \mathbf{H} \\
\text { KJ.mol }^{-1}\end{array}$ & $\begin{array}{c}-\Delta \mathbf{G} \\
\text { KJ.mol }^{-1}\end{array}$ & $\begin{array}{c}-\Delta \mathrm{S} \\
\text { J. } \mathrm{K}^{-1} \mathbf{m o l}^{-1}\end{array}$ \\
\hline 293.16 & \multirow{5}{*}{25.848} & 23.265 & 0.009 & \multirow{5}{*}{23.358} & 29.698 & 0.181 & \multirow{5}{*}{164.39} & ---- & ---- \\
\hline 298.16 & & 24.200 & 0.005 & & 30.266 & 0.180 & & 27.136 & 0.460 \\
\hline 303.16 & & 23.969 & 0.006 & & 31.563 & 0.181 & & 27.09 & 0.452 \\
\hline 308.16 & & 23.962 & 0.006 & & 32.315 & 0.180 & & 26.929 & 0.446 \\
\hline 313.16 & & 24.114 & 0.006 & & 33.191 & 0.182 & & 19.436 & 0.463 \\
\hline
\end{tabular}

We have found that the values of $\Delta H$ of ion-association in water and in ethanol are negative since ions are rigid and associated in a columbic interaction in a dielectric continuum media when the ion-pairs formed (Akrawi and Ali, 2009).

The values of $\Delta \mathrm{G}$ are negative indicating that the process occurs spontaneously. The negative values of $\Delta \mathrm{S}$ of 4-ASA in water, and ethanol have been considered as due to the increase in the orientation of solvent molecules when the ion - pairs formed (Akrawi and Ali, 2009).

The value of $\Delta \mathrm{H}$ for 4-ASA in methanol is positive and represents how much the ionsolvation is weakened by ion association. The positive value of $\Delta \mathrm{S}$ for 4-ASA in methanol has been considered as due to the decrease in the orientation of solvent molecules when the ion-pairs formed (Ali, 2006).

Table (4) shows the values of the equivalent conductivity with molar concentration of the three mixtures, (4-ASA+NiCl$),\left(4-\mathrm{ASA}+\mathrm{CoCl}_{2}\right)$ and $\left(4-\mathrm{ASA}+\mathrm{MnCl}_{2}\right)$, at different temperatures in water. It is clear from this table that the values of $\Lambda_{\text {equiv. }}$ decrease with increasing concentration of the metal added and increase with increasing of temperatures. From Figs. (5-7) it is clear the equivalent conductivity decreases with increasing metal concentration added. 


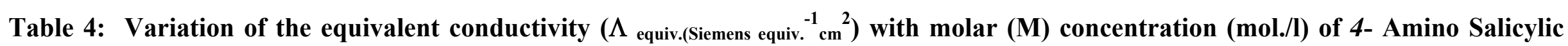
acid with some transition metals ions at different temperatures in water

\begin{tabular}{|c|c|c|c|c|c|c|c|c|c|c|c|c|c|c|c|}
\hline \multirow{2}{*}{$\begin{array}{c}\text { Metal ions } \\
\text { Temp./K } \\
\end{array}$} & \multicolumn{5}{|c|}{$\mathrm{Ni}^{2+}$} & \multicolumn{5}{|c|}{$\mathrm{Co}^{2+}$} & \multicolumn{5}{|c|}{$\mathrm{Mn}^{2+}$} \\
\hline & 293.16 & 298.16 & 303.16 & 308.16 & 313.16 & 293.16 & 298.16 & 303.16 & 308.16 & 313.16 & 293.16 & 298.16 & 303.16 & 308.16 & 313.16 \\
\hline$M \times 10^{5}$ & $\Lambda_{\text {equiv. }}$ & $\Lambda_{\text {equiv. }}$ & $\Lambda_{\text {equiv. }}$ & $\Lambda_{\text {equiv. }}$ & $\Lambda_{\text {equiv. }}$ & $\Lambda_{\text {equiv. }}$ & $\Lambda_{\text {equiv. }}$ & $\Lambda_{\text {equiv. }}$ & $\Lambda_{\text {equiv. }}$ & $\Lambda_{\text {equiv. }}$ & $\Lambda_{\text {equiv. }}$ & $\Lambda_{\text {equiv. }}$ & $\Lambda_{\text {equiv. }}$ & $\Lambda_{\text {equiv. }}$ & $\Lambda_{\text {equiv. }}$ \\
\hline 4.76 & 174.63 & 196.05 & 210.44 & 234.30 & 252.66 & 68.54 & 95.17 & 112.61 & 120.56 & 139.84 & 109.55 & 121.18 & 137.39 & 149.94 & 161.57 \\
\hline 4.55 & 123.92 & 130.28 & 140.01 & 152.72 & 161.14 & 48.43 & 65.26 & 74.43 & 86.02 & 95.93 & 78.54 & 82.65 & 89.39 & 100.61 & 111.08 \\
\hline 4.35 & 102.91 & 106.77 & 111.19 & 119.60 & 122.23 & 40.02 & 52.85 & 62.24 & 72.04 & 77.97 & 64.45 & 67.48 & 72.31 & 80.18 & 88.60 \\
\hline 4.17 & 92.66 & 92.77 & 93.88 & 101.34 & 101.45 & 35.72 & 46.07 & 54.97 & 63.87 & 67.81 & 56.53 & 58.31 & 62.87 & 67.99 & 75.55 \\
\hline 4.00 & 83.46 & 82.89 & 81.76 & 89.41 & 88.66 & 33.34 & 42.41 & 51.09 & 57.99 & 62.52 & 50.72 & 52.98 & 57.42 & 61.48 & 67.43 \\
\hline 3.85 & 76.55 & 76.63 & 75.06 & 81.19 & 79.54 & 31.16 & 39.37 & 47.82 & 53.70 & 56.94 & 47.16 & 48.73 & 51.63 & 56.27 & 61.24 \\
\hline 3.70 & 71.80 & 71.43 & 69.05 & 75.01 & 73.22 & 30.15 & 36.77 & 46.45 & 50.54 & 54.26 & 43.77 & 45.85 & 48.31 & 51.88 & 55.45 \\
\hline 3.57 & 67.91 & 67.64 & 64.44 & 70.36 & 68.25 & 29.38 & 34.68 & 44.47 & 48.08 & 51.48 & 42.02 & 43.45 & 45.70 & 49.50 & 53.45 \\
\hline 3.45 & 64.62 & 64.30 & 61.03 & 66.57 & 64.81 & 28.38 & 33.04 & 42.29 & 46.07 & 49.34 & 40.15 & 41.60 & 43.68 & 47.14 & 50.79 \\
\hline 3.33 & 62.01 & 62.01 & 58.30 & 63.42 & 61.95 & 27.89 & 32.25 & 41.25 & 44.25 & 47.84 & 38.90 & 40.07 & 41.90 & 45.25 & 48.72 \\
\hline 3.23 & 59.89 & 59.67 & 56.57 & 60.78 & 59.84 & 27.46 & 31.29 & 40.44 & 42.99 & 46.88 & 37.61 & 38.78 & 40.61 & 43.66 & 46.76 \\
\hline 3.13 & 57.95 & 57.79 & 55.16 & 58.63 & 57.68 & 26.95 & 30.17 & 39.85 & 41.54 & 45.80 & 36.48 & 37.69 & 39.38 & 42.33 & 45.17 \\
\hline 3.03 & 56.15 & 56.05 & 53.44 & 56.75 & 55.90 & 26.58 & 29.24 & 39.24 & 40.49 & 44.91 & 35.17 & 36.72 & 38.38 & 41.15 & 43.91 \\
\hline 2.94 & 54.56 & 54.70 & 52.39 & 55.04 & 54.12 & 26.20 & 28.85 & 38.77 & 40.17 & 44.12 & 34.25 & 35.45 & 37.47 & 40.17 & 42.77 \\
\hline 2.86 & 53.17 & 53.35 & 52.47 & 53.72 & 52.75 & 25.64 & 28.47 & 38.25 & 39.46 & 43.81 & 33.57 & 34.87 & 37.14 & 39.27 & 41.82 \\
\hline 2.78 & 52.11 & 52.20 & 52.38 & 52.51 & 51.80 & 25.08 & 27.99 & 37.79 & 39.18 & 42.99 & 32.73 & 34.21 & 36.45 & 38.56 & 40.93 \\
\hline 2.70 & 51.26 & 51.17 & 51.13 & 51.30 & 50.74 & 24.81 & 27.42 & 37.52 & 38.30 & 42.60 & 32.19 & 33.40 & 35.66 & 37.83 & 40.17 \\
\hline 2.63 & 50.16 & 50.29 & 50.00 & 50.29 & 49.95 & 24.48 & 27.09 & 37.03 & 37.66 & 41.84 & 31.56 & 32.69 & 35.31 & 37.24 & 39.48 \\
\hline 2.56 & 49.53 & 49.20 & 49.28 & 49.41 & 49.32 & 24.32 & 26.86 & 36.66 & 36.91 & 40.97 & 31.04 & 32.11 & 34.57 & 36.66 & 38.88 \\
\hline 2.50 & 48.31 & 48.51 & 48.71 & 48.59 & 48.35 & 23.92 & 26.52 & 36.28 & 36.32 & 40.24 & 30.56 & 31.64 & 33.92 & 36.16 & 38.28 \\
\hline
\end{tabular}




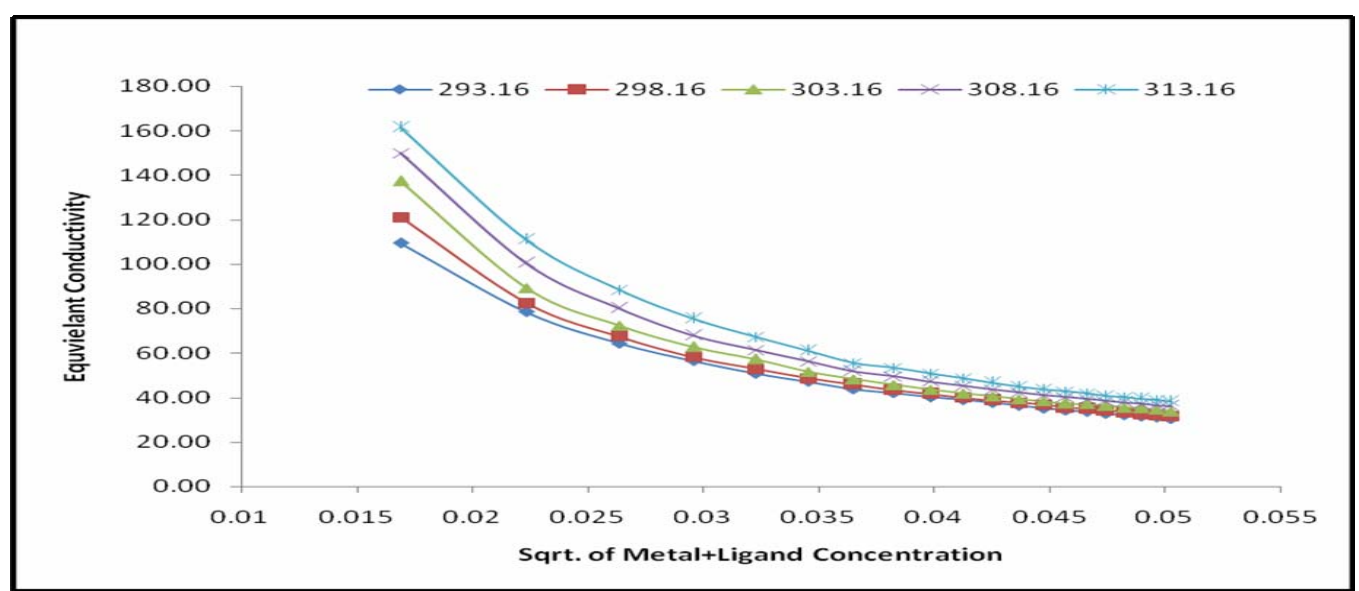

Fig. 5: Equivalent conductivity and the square root of Manganese chloride and ligand concentration $\left(\text { mol. }^{-1}\right)^{-1}$

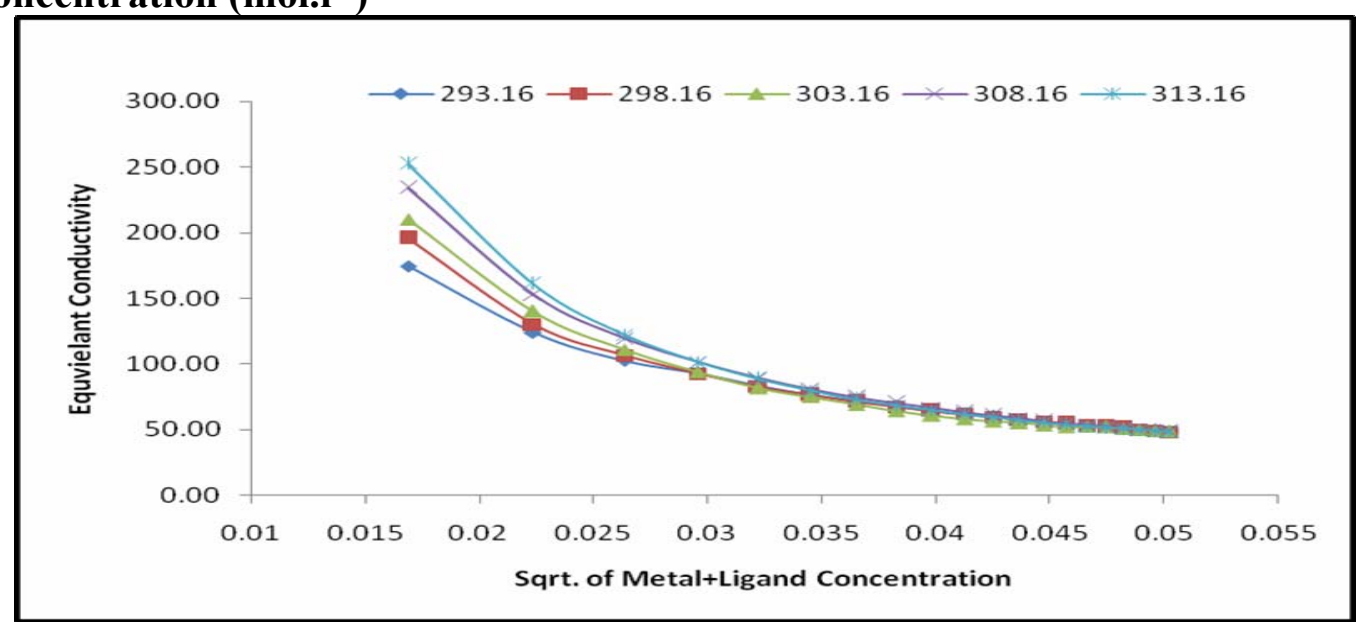

Fig. 6: Equivalent conductivity and the square root of Nickel chloride and ligand concentration $\left(\mathrm{mol}_{.} \mathrm{I}^{-1}\right)$

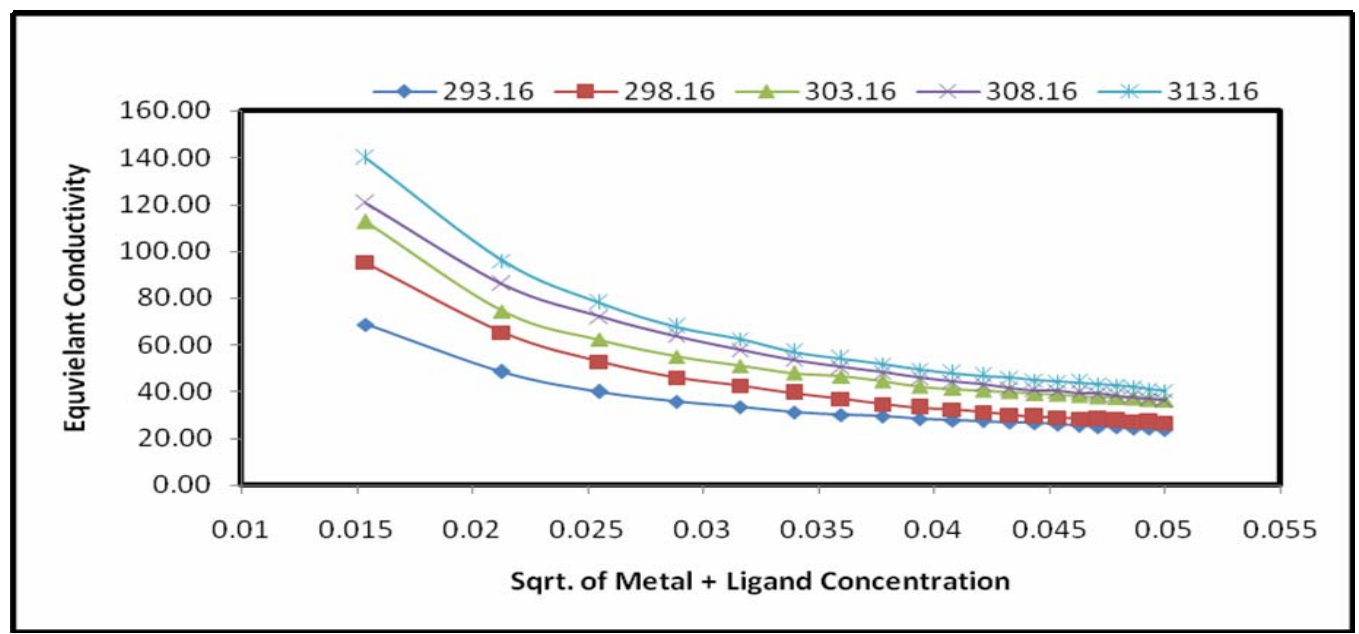

Fig. 7: Equivalent conductivity and the square root of Cobalt chloride and ligand concentration $\left(\mathrm{mol}_{.} \mathrm{I}^{-1}\right)$

The chemical equation which shows the expected complexes resulted from the addition of 4ASA to the metals chlorides 
Where $\mathrm{M}=\mathrm{Co}^{+2}, \mathrm{Ni}^{+2}, \mathrm{Mn}^{+2}, \mathrm{~L}=4-\mathrm{ASA}$

$$
\mathrm{MCl}_{2} \cdot 6 \mathrm{H}_{2} \mathrm{O}+\mathrm{L} \longrightarrow\left[\mathrm{ML}_{2}\right] \mathrm{Cl}_{2}
$$

The structure of the complexes expected to be tetrahedral is<smiles></smiles>

\section{M(II) bis 4-Amino Salicylic Acid chloride}

For the analysis of the electrolytes (4-ASA $\left.+\mathrm{CoCl}_{2}\right),\left(4-\mathrm{ASA}+\mathrm{NiCl}_{2}\right)$ and $\left(4-\mathrm{ASA}+\mathrm{MnCl}_{2}\right)$, a computer program $\left(\mathrm{RM}_{1}\right)$ was used for asymmetrical electrolytes in conductivity water for the data of concentration - conductivity measurements in which the input data are $(T, D, \eta)$ where $T$ is the temperature in Kelvin, $\mathrm{D}$ and $\eta$ are the dielectric constant and viscosity (poise) of the solvent at that temperature, $\mathrm{z}_{\mathrm{i}}$ (charge) and $\lambda_{\mathrm{i}}$ (ionic conductivity) for each species, $\mathrm{K}_{\mathrm{A}}{ }^{(1)}, \mathrm{K}_{\mathrm{A}}{ }^{(2)}, \lambda^{\circ} \mathrm{MX}^{+}, \lambda^{\circ} \mathrm{M}^{2+}$, and

$\mathrm{R}$ according to (LW) equation for $\mathrm{MX}_{2}$ electrolyte. $(\mathrm{MX})^{+}$

The analysis of the data shows that the cations an associated with anion to form a new species

$$
\begin{aligned}
& \mathrm{M}^{+2}+\mathrm{X}^{-} \stackrel{\mathrm{K}_{\mathrm{A}}^{(1)} \longrightarrow}{\longrightarrow}(\mathrm{MX})^{+} \\
& (\mathrm{MX})^{+}+\mathrm{X}^{-} \stackrel{\mathrm{K}_{\mathrm{A}}^{(2)} \longrightarrow}{\longrightarrow} \mathrm{MX}_{2}
\end{aligned}
$$

Tables (5-7) show the best fit parameters of analysis of conductance data using (LW) equation for the complex solutions of $\left(4-\mathrm{ASA}+\mathrm{CoCl}_{2}\right),\left(4-\mathrm{ASA}+\mathrm{MnCl}_{2}\right)$ and $\left(4-\mathrm{ASA}+\mathrm{NiCl}_{2}\right)$ in water at different temperatures.

Table 5: Best fit parameters of analysis of conductance data for $\left[4-\mathrm{ASA}+\mathrm{CoCl}_{2}\right]$ in water at different temperatures

\begin{tabular}{|c|c|c|c|c|c|c|}
\hline $\begin{array}{c}\text { Temp. } \\
(\mathbf{K})\end{array}$ & $\boldsymbol{\lambda}_{\mathbf{M}}{ }^{2+}$ & $\boldsymbol{\lambda}_{\mathbf{M x}}{ }^{+}$ & $\mathbf{K}_{\mathbf{A}(\mathbf{1})}$ & $\mathbf{K}_{\mathbf{A}(\mathbf{2})}$ & $\mathbf{R} / \mathbf{A}^{\mathbf{0}}$ & $\sigma \mathbf{S}(\mathbf{\Lambda})$ \\
\hline 293.16 & 10 & 0.2 & 0.0 & $10^{7}$ & 30 & 1.040 \\
\hline 298.16 & 20 & 0.2 & 0.0 & 250000 & 10 & 0.317 \\
\hline 303.16 & 50 & 0.2 & 0.0 & 11500 & 8 & 1.102 \\
\hline 308.16 & 69 & 0.2 & 0.0 & 5550 & 8 & 2.427 \\
\hline 313.16 & 120 & 0.2 & 0.0 & 5000 & 8 & 6.384 \\
\hline
\end{tabular}

Table 6: Best fit parameters of analysis of conductance data for $\left[4-\mathrm{ASA}+\mathrm{MnCl}_{2}\right]$ in water at different temperatures

\begin{tabular}{|c|c|c|c|c|c|c|}
\hline $\begin{array}{c}\text { Temp. } \\
(\mathbf{K})\end{array}$ & ${\boldsymbol{\lambda}_{\mathbf{M}}{ }^{2+}}$ & $\boldsymbol{\lambda}_{\mathbf{M X}}{ }^{+}$ & $\mathbf{K}_{\mathbf{A}(\mathbf{1})}$ & $\mathbf{K}_{\mathbf{A}(\mathbf{2})}$ & $\mathbf{R} / \mathbf{A}^{\mathbf{0}}$ & $\sigma \mathbf{S}(\mathbf{\Lambda})$ \\
\hline 293.16 & 135 & 0.2 & 0.0 & 11000 & 8 & 1.367 \\
\hline 298.16 & 180 & 0.2 & 0.0 & 13500 & 10 & 8.897 \\
\hline 303.16 & 220 & 0.2 & 0.0 & 15000 & 10 & 3.350 \\
\hline 308.16 & 250 & 0.2 & 0.0 & 13000 & 10 & 5.470 \\
\hline 313.16 & 135 & 0.2 & 0.0 & 15000 & 8 & 5.461 \\
\hline
\end{tabular}


Table 7: Best fit parameters of analysis of conductance data for [4-ASA+NiCl ] in water at different temperatures

\begin{tabular}{|c|c|c|c|c|c|c|}
\hline $\begin{array}{c}\text { Temp. } \\
(\mathbf{K})\end{array}$ & $\boldsymbol{\lambda}_{\mathbf{M}}{ }^{2+}$ & $\lambda_{\mathbf{M x}}{ }^{+}$ & $\mathbf{K}_{\mathbf{A}(\mathbf{1})}$ & $\mathbf{K}_{\mathbf{A}(\mathbf{2})}$ & $\mathbf{R} / \mathbf{A}^{\mathbf{0}}$ & $\sigma \mathbf{S}(\mathbf{\Lambda})$ \\
\hline 293.16 & 580 & 0.2 & 0.0 & 12000 & 30 & 1.042 \\
\hline 298.16 & 680 & 0.2 & 0.0 & 10500 & 30 & 5.196 \\
\hline 303.16 & 650 & 0.2 & 0.0 & 13000 & 30 & 1.371 \\
\hline 308.16 & 1000 & 0.2 & 0.0 & 18500 & 30 & 5.606 \\
\hline 313.16 & 1000 & 0.2 & 0.0 & 21000 & 30 & 7.196 \\
\hline
\end{tabular}

The above tables show generally that $\lambda_{\mathrm{M}}{ }^{2+}$ for the three ions increases with increasing temperatures for the three electrolytes, where $\lambda_{\mathrm{M}}{ }^{2+}$ for $\left(4-\mathrm{ASA}+\mathrm{NiCl}_{2}\right)>\lambda_{\mathrm{M}}{ }^{2+}\left(4-\mathrm{ASA}+\mathrm{MnCl}_{2}\right)>$ $\lambda_{\mathrm{M}}{ }^{2+}\left(4-\mathrm{ASA}+\mathrm{CoCl}_{2}\right)$, since $\mathrm{Co}^{2+}$ is the smallest cation and the more solvated ion. For the (4-ASA $+\mathrm{CoCl}_{2}$ ) electrolyte the value of $\mathrm{K}_{\mathrm{A}(2)}$ decreases with increasing of temperature. This may be due to the effect of short range interaction and the hydrogen bonding formed at low temperature. For the other two electrolytes, $\mathrm{K}_{\mathrm{A}(2)}$ increases with increase of temperature which assumed a simple coulombic interaction between hard sphere ions in a continuous medium. Besides, such an increase of $\mathrm{K}_{\mathrm{A}}$ is partly due to a decrease in the dielectric constant and partly can be explained in term of diminution in dielectric constant in the vicinity of an ion-pair and decreasing the density of solvent (Weast, 1974). The $\mathrm{R}$ values obtained are generally (8-30) $\mathrm{A}^{\mathrm{O}}$ which indicates that the cations and anions are separated by many water molecules. The relative values of $\sigma s(\Lambda)$ indicate the good applicability of (LW) equation for such a study. The thermodynamic parameters $(\Delta \mathrm{G}, \Delta \mathrm{H}$ and $\Delta \mathrm{S})$ for 4-ASA complex in water are calculated as mentioned before. Table (8) shows the calculated values.

Table 8: Thermodynamic parameters from the ion association constant of 4-ASA with $\mathrm{CoCl}_{2}$, $\mathrm{NiCl}_{2}$ and $\mathrm{MnCl}_{2}$ in water at different temperatures

\begin{tabular}{|c|c|c|c|c|c|c|c|c|c|}
\hline $\begin{array}{c}\text { Metal } \\
\text { chloride }\end{array}$ & \multicolumn{3}{|c|}{$\mathrm{CoCl}_{2}$} & \multicolumn{3}{|c|}{$\mathrm{NiCl}_{2}$} & \multicolumn{3}{|c|}{$\mathbf{M n C l}_{2}$} \\
\hline $\begin{array}{c}\text { Temp. } \\
\text { (K) }\end{array}$ & $\begin{array}{c}-\Delta \mathbf{H} \\
\text { KJ.mol }^{-1}\end{array}$ & $\begin{array}{c}-\Delta \mathbf{G} \\
\text { KJ.mol }^{-1}\end{array}$ & $\begin{array}{c}-\Delta \mathrm{S} \\
\mathrm{J} . \mathrm{K}^{-1} \mathrm{~mol}^{-1}\end{array}$ & $\begin{array}{c}\Delta \mathbf{H} \\
\text { KJ.mol }^{-1}\end{array}$ & $\begin{array}{c}-\Delta \mathbf{G} \\
\text { KJ.mol }^{-1}\end{array}$ & $\begin{array}{c}\Delta \mathrm{S} \\
\text { J. } \mathrm{K}^{-1} \mathrm{~mol}^{-1}\end{array}$ & $\begin{array}{c}-\Delta \mathbf{H} \\
\text { KJ.mol }^{-1}\end{array}$ & $\begin{array}{c}-\Delta G \\
\text { KJ.mol }^{-1}\end{array}$ & $\begin{array}{c}\Delta \mathrm{S} \\
\mathrm{J} . \mathrm{K}^{1} \mathrm{~mol}^{-1}\end{array}$ \\
\hline 293.16 & \multirow{5}{*}{286.397} & 39.285 & 0.843 & \multirow{5}{*}{22.938} & 22.893 & 0.156 & \multirow{5}{*}{18.531} & 22.680 & 0.141 \\
\hline 298.16 & & 30.810 & 0.57 & & 23.384 & 0.155 & & 23.576 & 0.141 \\
\hline 303.16 & & 23.566 & 0.866 & & 23.875 & 0.154 & & 24.236 & 0.141 \\
\hline 308.16 & & 22.088 & 0.857 & & 25.173 & 0.156 & & 24.801 & 0.141 \\
\hline 313.16 & & 22.176 & 0.844 & & 25.911 & 0.156 & & 28.17 & 0.149 \\
\hline
\end{tabular}

For 4-ASA with $\mathrm{CoCl}_{2}$ the negative value of $\Delta \mathrm{H}$ and $\Delta \mathrm{G}$ values (Table 8) can be explained by interaction in the ion-association process. But the binding entropy $(\Delta \mathrm{S})$ between the ions was found to be negative to unfavour the ion-association process and thus favoring ion solvation process (Sarkar et al., 2009).

For 4-ASA with $\mathrm{NiCl}_{2}$ (Table 8 ) the value of $(\Delta \mathrm{H})$ is positive which may mean that the temperature dependence of dielectric constant which represents how much the ion -solvation is weakened by ion-association. The positive values of $(\Delta S)$ have been considered as due to the decreased orientation of solvent molecules when the ion-pair forms. The values of $\Delta \mathrm{G}$ of the ionassociation are negative and should depend on the kind of the ion (Doe et al., 1990). For 4-ASA with $\mathrm{MnCl}_{2}$ (Table 8), it was found that the value of $\Delta \mathrm{H}$ of ion-association is negative since ions are rigid and associated in a coulombic interaction in a dielectric continuum media. The values of $\Delta \mathrm{G}$ are negative indicating that the process occurs spontaneously. The positive value of $\Delta \mathrm{S}$ has been 
considered as due to the decrease in the orientation of solvent molecules when the ion-pair form, is explained by the fact of the solvent of $\mathrm{M}^{2+}$ and weakened by the ion pairing of $\mathrm{MX}^{+}$(Doe et al., 1990).

The plot of Walden-product against reciprocal dielectric constant is shown in Figs. (8- 10). It is clear that $\Lambda_{\mathrm{o}} \eta$ decreases with increasing the dielectric constant. This variation in Walden-product reflects the change of the total solvations. The decrease of the Walden-product indicates an increase of the total solvation with increasing of the dielectric constant. The decrease of dielectric constant of the solvent will increase the solvating power of that solvent, and causes the ion to move with only the primary solvation shell in the solvent and the effect of the secondary solvation appears to be very small.

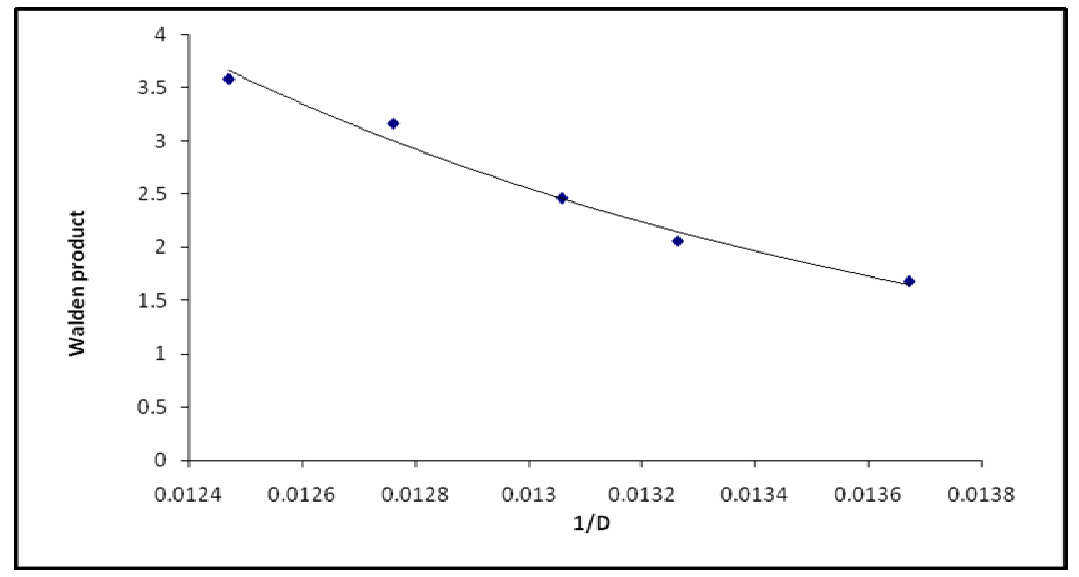

Fig. 8: Walden - product for 4-ASA in water

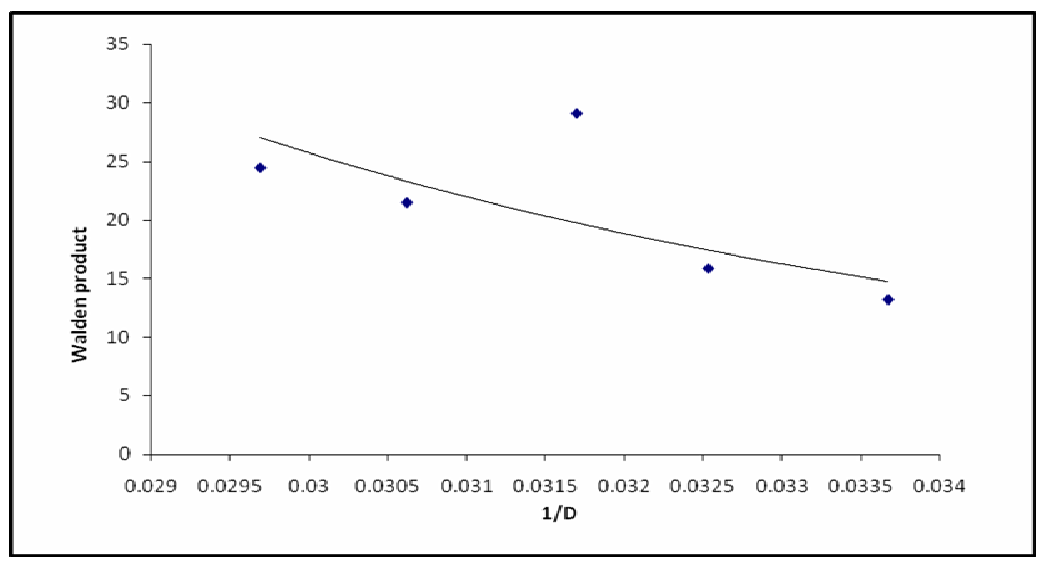

Fig. 9: Walden - product for 4-ASA in methanol

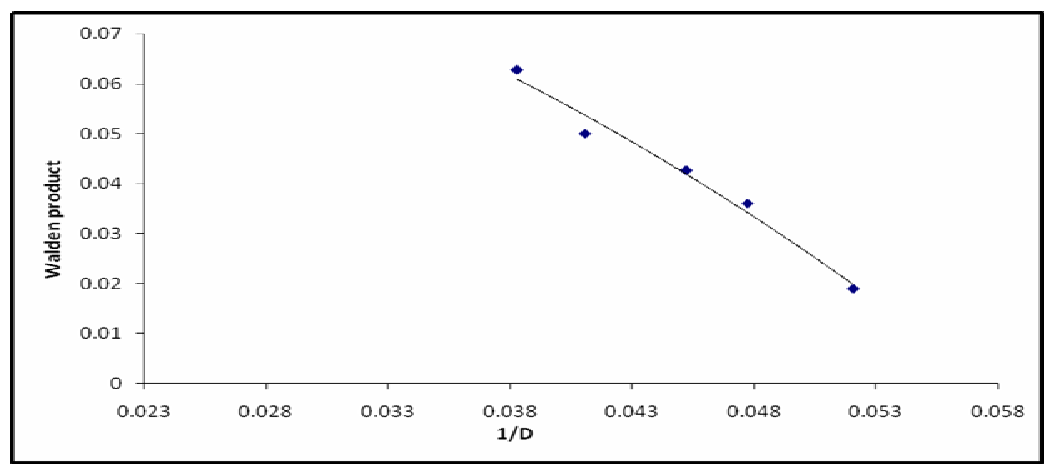

Fig. 10: Walden - product for 4-ASA in ethanol 


\section{REFERENCES}

Akrawi, B.A.; Khalil, S.M.; Dawod, A.M. (2006). The electrical conductivity of potassium halides in methanol at different temperatures. J. Raf. Sci., 17(4), Chemistry, Special Issue, 68-75.

Akrawi, B.A.; Ali, A.M.J. (2009). Conductivity measurement of barbituric acid (BA) drug and its complexes with alkaline-earth metal chloride. National J. Chemistry, 36, 614-633.

Akrawi, B.A.M. (1981). Electroanalytical chemistry. The analysis of conductance data for single and mixed electrolyte solution. Ph.D thesis, University of Surrey.

Ali, A.M.J. (2006). Ionic association of complexes of 2,2'-bipyridyl with some transition metal ions in different media and synthesized complexes of barbituric acid with some alkaline earth metal using conductivity. Ph.D. Thesis, University of Mosul.

Doe, H.; Ohe, H.; Matoba, H.; Jchimura, A.; Kitagoma, T. (1990). Conductometric study of Calcium (II), Strontinum (II), and Barium (II) Perchlorates in Methanol Ethylene Glycol Mixtures. Bull. Chem. Soc. J. pns, 63, 2785-2789.

Fuoss, R.M. (1958). Ionic Association III. The Equilibrium Between Ion Pairs and Free Ions. J. Amer. Chem. Soc. 80, 5059-5061.

http://dailymed.nlm.gov/dailymed/druginfo. (2013).

http://en.wikipedia.org/wiki/4-AminoSalicylicacid . (2013).

Lee, W.H.; Wheaton, R.J. (1978). Conductance of symmetrical, unsymmetrical and mixed electrolytes. Faraday Transitions II part 1. Relaxation Terms, 74, 743-765.

Lee, W.H.; Wheaton, R.J. (1978). Conductance of symmetrical, unsymmetrical and mixed electrolytes. part 2. hydrodynamic terms and complete conductance equation. Faraday Transitions II, 74, 1456-1482.

Niazi, M.S.K.; M.Z.I. (1993). Thermodynamic dissociation constants of salicylic and monochloro acetic acids in mixed solvent systems from conductance measurements at $25^{\circ} \mathrm{C}$. J. Solution Chemistry, 22(5), 437-456.

Niazi, M.S.K.; Shah, S.S.; Khan, M.Z.I. (1993). Conductivities and thermodynamic dissociation constant for salicylic acid in binary mixed solvent systems at $298.5 \mathrm{~K}$. J. Chemical and Engineering Data. 38(2), 288-291.

Papadopoulos, N.; Avranas, A. (1991). Dissociation of Salicylic Acid, 2,4-,2,5- and 2,6dihydroxybenzoic Acids in 1-propanol-water Mixtures at $25^{\circ}$ C. J. Solution Chemistry, 20(3), 293-300.

Sarkar, F.W.; Nielse, J.K.; Stanley, H.E. (2009). Hydrogen - Bond dynamics for the extended simple point - charge model of water. Physical Review, 62(1).

Weast, R. (1974). "Hand Book of Chemistry and Physics CRC PRESS". 55th edn. 